SNEŽANA GOLUBOVIĆ

Archaeological Institute

Belgrade, Serbia

arheosneska@gmail.com

NEMANJA MRĐIĆ

Archaeological Institute

Belgrade, Serbia

nemanjamrdjic@gmail.com
904:725.182”652”(497.11)

930.85(497.11:100)

COBISS.SR-ID 212292620

Original research article

Received: January 14, 2014

Accepted: February 15, 2014

\title{
DANUBE LIMES AS A UNESCO WORLD HERITAGE SITE
}

\begin{abstract}
The Roman frontier or limes was a continuous line of fortifications connected by a system of roads and river ports defending the empire. Large rivers like the Rhine and the Danube were used as primary barriers against barbarian attacks. The frontier spread over three continents and consisted of thousands of sites that belonged to many different types and categories: cities and other settlements, legionary and auxiliary forts, watchtowers and cemeteries etc.

"Frontiers of the Roman Empire" is a complex, phased and trans-national UNESCO world cultural heritage project. Limes in general meet three cultural criteria for the World Heritage List. Parts of limes were already ascribed to the list. Several other countries have all started their nomination processes. The Limes in Serbia is a natural extension of this project, especially recommended by UNESCO authorities. The advantage of inscribing the limes in Serbia to the World Heritage List is that all the major argumentation has already been proved and attested. Being inscribed to the UNESCO World Heritage List means that the site must be physically protected, presented and has an organised management system. Where major sites are concerned, the presentation and protection of the Danube limes in Serbia is actually a part of the already ongoing project Itinerarium Romanum Serbiae, recognised by the EU and professional authorities.
\end{abstract}

Keywords: Roman Limes, Roman Empire, Danube, UNESCO, World Heritage List, Serbia, frontier

\section{INTRODUCTION*}

The Roman frontier, or Limes, was a continuous line of fortifications connected by a system of roads and river ports which defended the empire. Troop commanders used natural obstacles to improve their defensive positions. Large rivers like the Rhine and the Danube were used as primary barriers against barbarian attacks with an organised military infrastructure along the Empire's borders. The frontier spread over three continents and consisted of thousands of sites that belonged to many different types and categories: cities and other settlements, legionary and auxiliary forts, watchtowers and cemeteries etc. The continuous presence of troops, who were highly paid, brought merchants and craftsmen to the frontier. Soon large urban centres emerged and rivers become one of the most important trade routes. The frontiers become highly developed regions and, with

* The article results from the project: IRS - Viminacium, Roman city and military legion camp - research of material and non material culture of inhabitants by using the modern technologies of remote detection, geophysics, GIS, digitalisation and $3 D$ visualisation (no 47018), funded by Ministry of Education, Science and Technological Development of the Republic of Serbia and European project Danube limes Brand. 


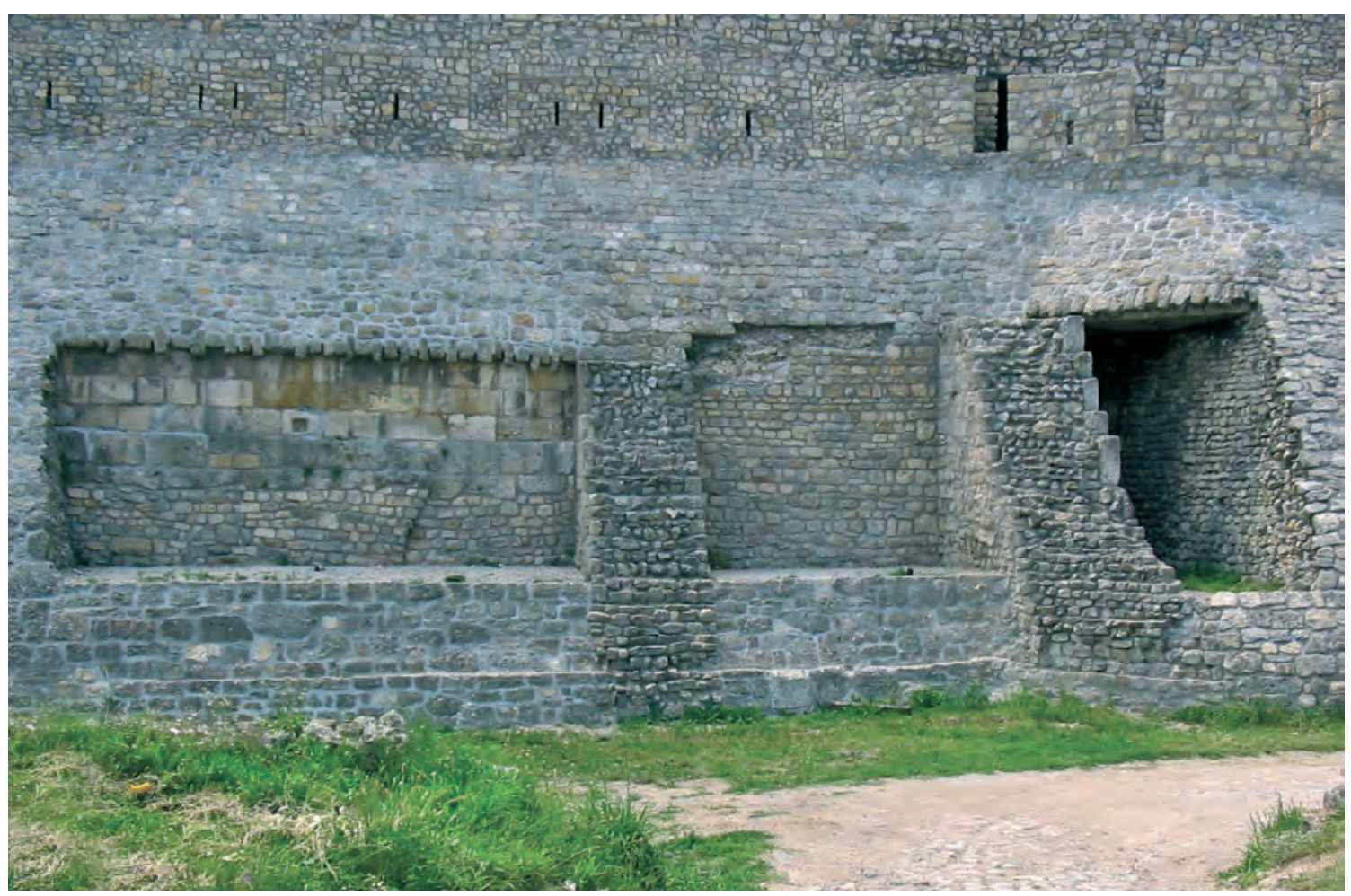

Fig. 1 Singidunum - Roman fort wall incorporated into the later fortification

the army being the bearer of Romanisation, the Limes transformed into a unique zone that, today, really can be seen as the outstanding legacy of Roman civilisation.

The ultimate goal of the entire project is to inscribe all Roman limes sections to the UNESCO World Heritage List. Finally, the Roman limes can be considered as the largest archaeological complex in the world.

\section{ROMAN LIMES AS THE UNESCO WORLD HERITAGE SITE}

"Frontiers of the Roman Empire" 1 is a complex, phased and trans-national UNESCO world cultural heritage project. Parts of limes in the United Kingdom and Germany have already been inscribed to the list. Hadrian's Wall (United Kingdom) was the first part of the frontier inscribed in 1987. In 2005, the Upper German-Raetian Limes followed as along with the Antonine Wall in Scotland, in 2008 (Breeze 2009). Justification of the limes as a linear site of outstanding universal value was already accepted with the first nomination.

1 http://whc.unesco.org/en/list/430/
All other nominations are now considered as the extension and every project ads its own unique features to the already existing ones. Danube is the next step in completing the nomination of the Limes in Europe (Jilek 2009).

The project enhances the long-term preservation for future generations through the development of a harmonised, transnational, "joint action plan" for all Danube countries in respect of protection, conservation, management and presentation of Limes monuments and sites. It helps to create a link between individual regions and sites and to create local and regional identities. It promotes further cultural and civil society cooperation and contributes to economic and tourism development.

The Danube Limes, as a future World Heritage Site shared by all Danube countries, is listed in the Danube Area Strategy (EUSDR) as a flagship project under the action: To promote cultural exchange and exchange in arts. The new SEE project application is a follow-up of the former CE project "Danube Limes - UNESCO World Heritage“ 2008-2011. It capitalises on its results, based mainly on the experiences during the successful preparation of the UNESCO nomination documents on the Danube Limes heritage 


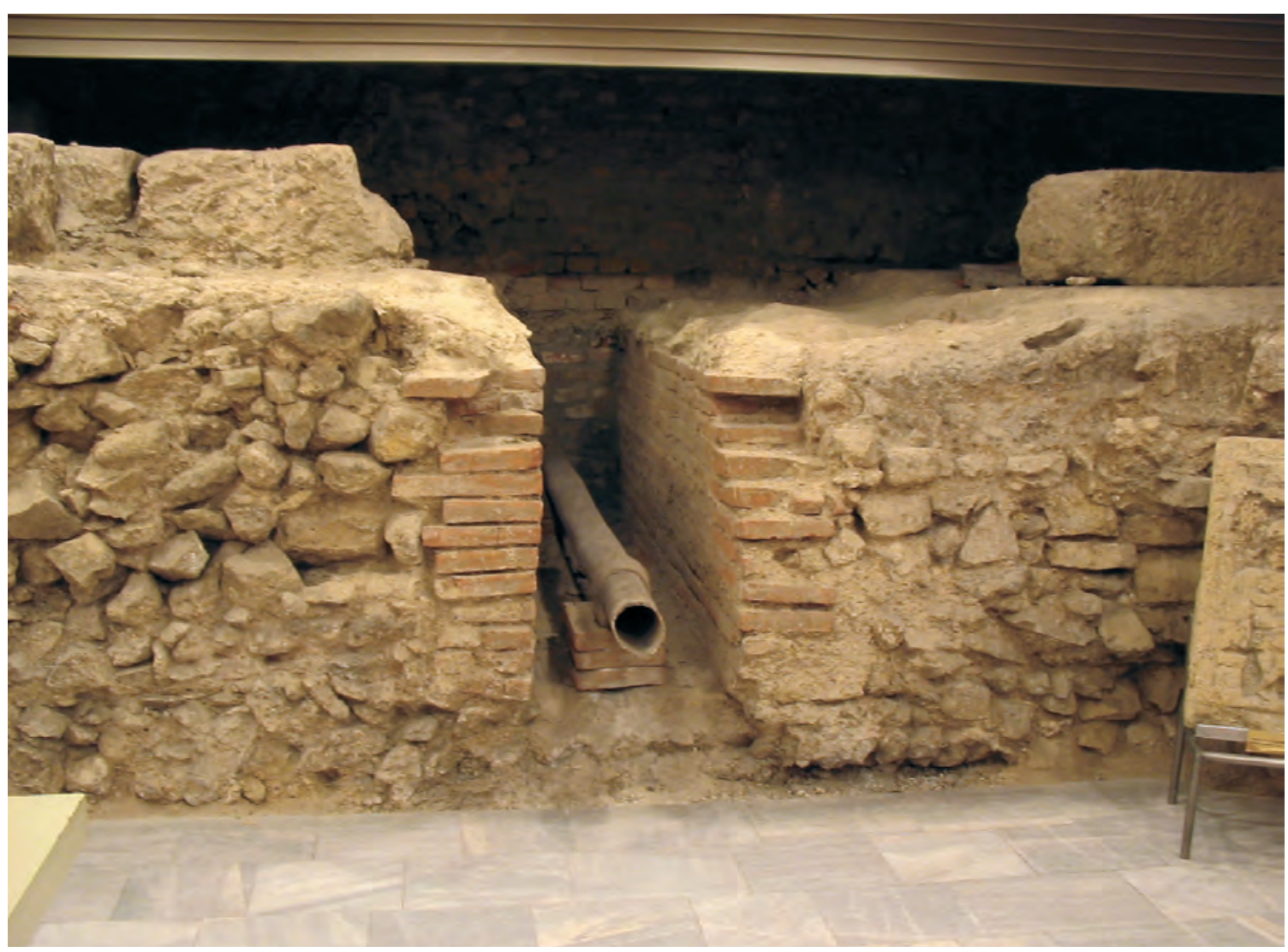

Fig. 2 Singidunum - Roman fort gate preserved in the Belgrade library Roman hall

in Hungary and Slovakia².

Austria (Jilek et al 2011), Hungary, Slovakia and Croatia have all started their nomination processes. Hungary and Slovakia have already prepared full nomination documentation and it now only depends on the governmental structure as to when the procedure will be finished. Serbia, on the other hand, is just taking the first steps towards the tentative list and nomination.

According to the UNESCO nomination regulations, all nominated sites must be of "outstanding universal value" and meet at least one of the criteria. Since 2005, there has been one set of ten criteria for nominating sites to the World Heritage List: 6 cultural criteria and 4 natural criteria. ${ }^{3}$

The Roman limes meets three out of the six cultural criteria that are evaluated for every World Heritage Site. These criteria are 2, 3 and 4.

(ii) to exhibit an important interchange of human values, over a span of time or within a cultural area of the world, on developments in architecture or technology, monumental arts,

2 http://www.danube-limes.eu; Lesak et al, 2013 3 http://whc.unesco.org/en/criteria/ town-planning or landscape design;

(iii) to bear a unique or at least exceptional testimony to a cultural tradition or to a civilisation which is living or which has disappeared;

(iv) to be an outstanding example of a type of building, architectural or technological ensemble or landscape which illustrates (a) significant stage(s) in human history;

Research of Limes is one of the most thorough archaeological activities among experts from all countries of the world. The results of this research are often presented at the Limes Congress - a regular congress held every three years.

\section{PREPARATION FOR THE NOMI- NATION OF THE SERBIAN LIMES SECTION}

Being inscribed to the UNESCO World Heritage List means that the site must be physically protected, presented and has an organised management system. Since this is not the actual situation in the field, work must be undertaken in 


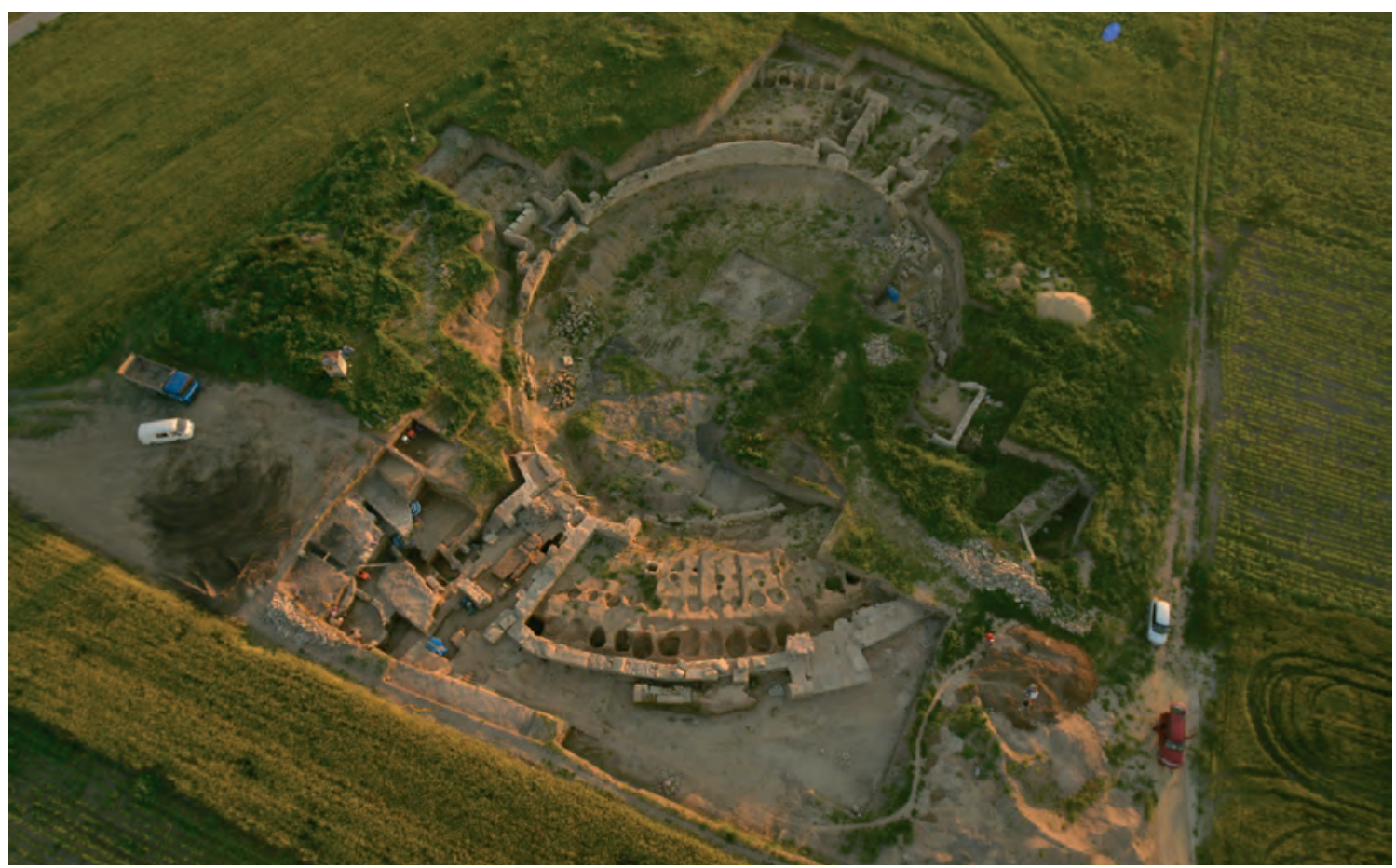

Fig. 3 Viminacium - Amphitheatre, aerial view during excavations

order to prepare it for nomination. An effective management system depends individually on the type, characteristics and needs of the site and its cultural context. Government, regional and local authorities must all be involved in presenting archaeological remains. Popularisation and education related to Roman heritage is essential since it will help raise awareness of its importance among the local population and help with the preservation of archaeological remains.

Where major sites are concerned, the presentation and protection of the Danube limes in Serbia is actually a part of the already ongoing project Itinerarium Romanum Serbiae, recognised by the EU and professional authorities.

The Tentative List is the first step in the nomination of all sites. It is only a preliminary list, an inventory of those properties which each State Party intends to consider for nomination. This list is flexible, can be modified prior to nomination and is not binding. When the nomination is accepted and the property becomes part of the World Heritage List, states are obliged to respect all conditions prescribed by UNESCO.

There are 11 properties submitted by Serbia on the Tentative List for both cultural and natural heritage:

- Djerdap National Park (2002)
- The Deliblato Sands Special Natural Reserve (2002)

- Mt. Šara National Park (2002)

- The Tara National Park with the Drina River Canyon (2002)

- The Djavolja Varoš (Devil's Town) Natural Landmark (2002)

- Fortified Manasija Monastery (2010)

- Negotinske Pivnice (2010)

- Smederevo Fortress (2010)

- Caričin Grad - Iustiniana Prima, archaeological site (2010)

- Historical place of Bač and its Surroundings (2010)

- Stećak's - Medieval Tombstones (2011)

At the moment, the Republic of Serbia has 4 World Heritage sites ${ }^{4}$, of which 3 are mediaeval monasteries with other archaeological elements (fortified city etc.). Only one site is archaeological and belongs to the antiquity - Gamzigrad (Felix Romuliana).

World Heritage list - sites in the Republic of Serbia

- Cultural-Historical Region of Stari Ras and Sopoćani Monastery (1979)

- Studenica monastery (1986)

4 http://whc.unesco.org/en/statesparties/rs 


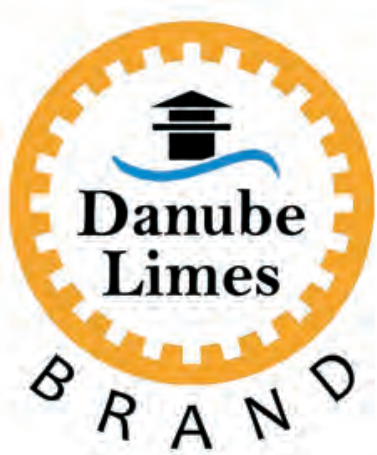

- Medieval Monuments in Kosovo (2004, 2006) Dečani Monastery, Patriarchate of Peć, Gračanica

- Monastery, Our Lady of Ljeviš (2006)

- Gamzigrad - Felix Romuliana (2007)

The Institute for the Protection of Cultural Monuments of the Republic of Serbia is the competent institution to prepare a nomination of cultural heritage. The government has a Permanent Delegation to UNESCO in Paris and the Commission of the Republic of Serbia for UNESCO that is part of the Ministry of Foreign Affairs of the Republic of Serbia.

The Serbian nomination of the Danube limes will not be an individual nomination which is most common where UNESCO is concerned. This will be an extension of the existing transnational and serial property "Frontiers of the Roman Empire" as discussed in previous chapters.

Experts from all institutions in Serbia are now organised in a work group that began its activities in autumn 2013. A preliminary register of the archaeological sites has been formed and preparation of the tentative list is in progress. The Archaeological Institute and the Institute for the Protection of the Cultural Heritage of the Republic of Serbia are the leading institutions in the workgroup.

\section{DANUBE LIMES BRAND ${ }^{5}$}

Danube Limes Brand is the project co-funded by the European Union and one of the best examples of multinational cooperation of experts from countries along The Danube. Nine partners from seven countries gathered to prepare the base

5 http://danubelimesbrand.org/ for the nomination - an extension of the project "Frontiers of the Roman Empire".

The DANUBE LIMES BRAND Project fosters the sustainable utilisation of the cultural Danube Limes heritage (archaeological sites, monuments and landscape) under the UNESCO World Heritage designation. The DANUBE LIMES BRAND project concentrates on:

1. Preparation of additional Danube Limes UNESCO heritage nominations in the Lower Danube area (Croatia, Serbia, Romania, Bulgaria);

2. Development of general branding for the future joint exploitation of the economic and tourism potential of the Danube Limes heritage with the input of best practice models from all participating countries;

3. Investigation of the regional potential for the exploitation of the Limes heritage on a national/regional level and the preparation of national/ regional presentation concept studies in all partner countries;

4. Implementation of some measures of the presentation concept as pilot actions on a local/ regional/national level to function as role models for the exploitation of a common perspective Danube Limes World Heritage Site.

It is important to make basic preparations for the nomination of all sites (documentation, conservation, presentation and visualisation). Media attention and tourist promotion are also important to achieve.

An important focus is also the exchange of knowledge and experience through the tight coordination of experts from all partners. All partners are listed in table 1 below.

Within the project, each partner has a different role and different goals, since every country follows its own legislation related to the process 


\begin{tabular}{|c|c|}
\hline Project Partners & Associated Partners \\
\hline $\begin{array}{l}\text { Lead partner } \\
\text { Institute for History, University of Vienna } \\
\text { Vienna, Austria } \\
\text { http://www.univie.ac.at/Geschichtsforschung }\end{array}$ & $\begin{array}{l}\text { Danube Working Community } \\
\text { St. Pölten, Austria } \\
\text { http://www.arge.donau.at }\end{array}$ \\
\hline $\begin{array}{l}\text { Department for Building and Environment, } \\
\text { Centre for Architectural Heritage } \\
\text { and Infrastructure, Danube University Krems } \\
\text { Krems, Austria } \\
\text { http://www.donau-uni.ac.at/en/department/ } \\
\text { bauenumwelt/zentrum/baukulturelles_erbe/ } \\
\text { index.php }\end{array}$ & $\begin{array}{l}\text { Eco-Museum Research Institute Tulcea } \\
\text { Tulcea, Romania } \\
\text { http://www.icemtl.ro }\end{array}$ \\
\hline $\begin{array}{l}\text { Municipal Monument Preservation Institute in } \\
\text { Bratislava } \\
\text { Bratislava, Slovakia } \\
\text { http://muop.bratislava.sk }\end{array}$ & $\begin{array}{l}\text { Federal Ministry for Education, Arts and } \\
\text { Culture } \\
\text { Vienna, Austria } \\
\text { http://www.bmukk.gv.at }\end{array}$ \\
\hline $\begin{array}{l}\text { Institute of Tourism, Regional Development and } \\
\text { Foreign Languages, Károly Róbert College } \\
\text { Gyöngyös, Hungary } \\
\text { http://www.karolyrobert.hu }\end{array}$ & $\begin{array}{l}\text { National Tourism Organization of Serbia } \\
\text { Belgrade, Serbia } \\
\text { http://www.serbia.travel }\end{array}$ \\
\hline $\begin{array}{l}\text { Province of Rimini } \\
\text { Rimini, Italy } \\
\text { http://www.provincia.rimini.it }\end{array}$ & $\begin{array}{l}\text { PUSR - The Monuments Board of the Slovak } \\
\text { Republic } \\
\text { Bratislava, Slovakia } \\
\text { http://www.pamiatky.sk }\end{array}$ \\
\hline $\begin{array}{l}\text { National Institute for Heritage } \\
\text { Bucharest, Romania } \\
\text { http://www.monumenteistorice.ro }\end{array}$ & \\
\hline $\begin{array}{l}\text { Institute of Archaeology and Museum, } \\
\text { Bulgarian Academy of Sciences } \\
\text { Sofia, Bulgaria } \\
\text { http://www.naim.bg/ }\end{array}$ & \\
\hline $\begin{array}{l}\text { Archaeological Institute, } \\
\text { Serbian Academy of Sciences } \\
\text { Belgrade, Serbia } \\
\text { http://www.ai.ac.rs }\end{array}$ & \\
\hline $\begin{array}{l}\text { Museum of Slavonia Osijek } \\
\text { Osijek, Croatia } \\
\text { http://arheoloskimuzejosijek.hr/ }\end{array}$ & \\
\hline
\end{tabular}

Table 1 - Participants in the project Danube Limes Brand. 


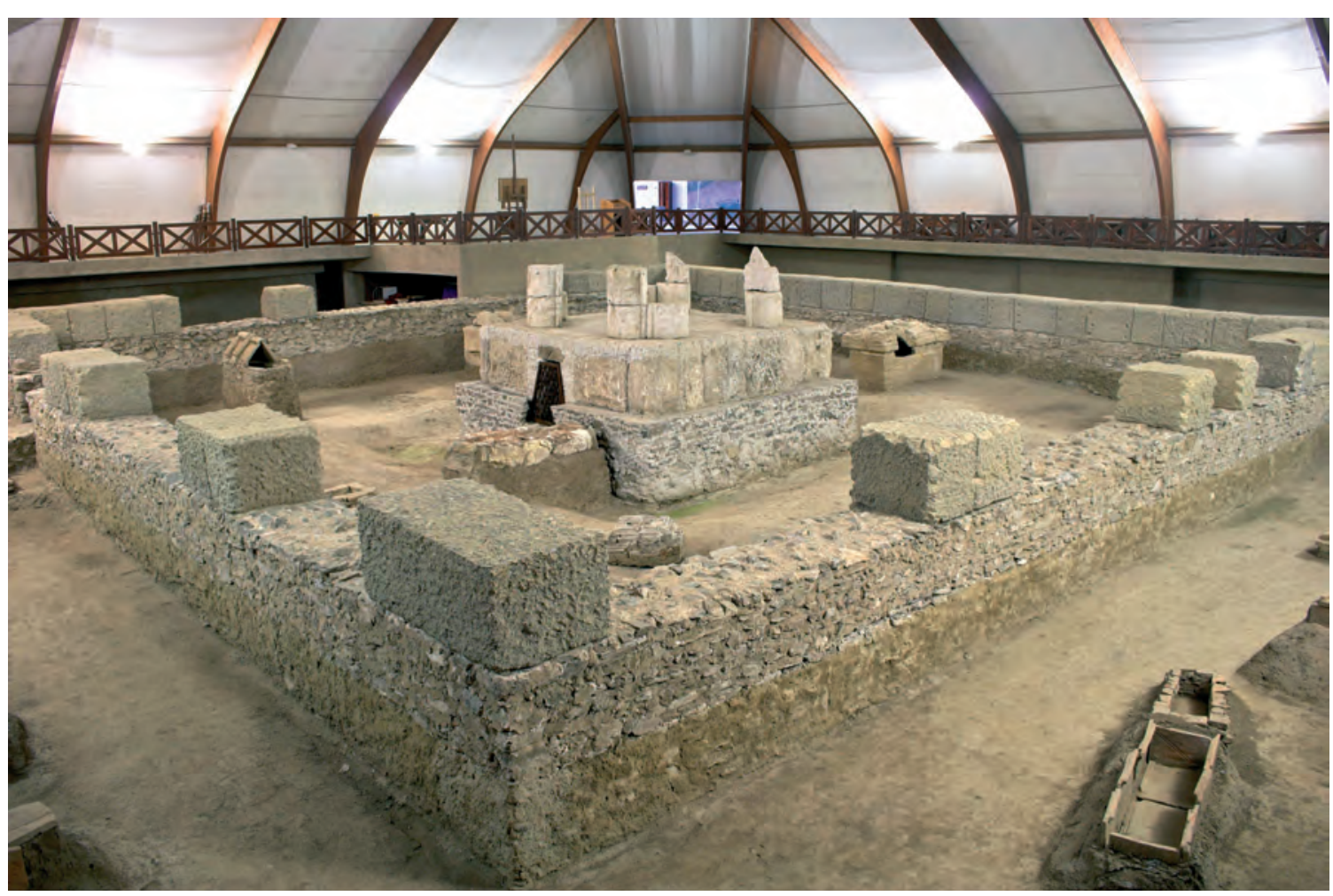

Fig. 4 Viminacium - Eastern cemetery and mausoleum

and is in a different phase of nomination. Among the goals of Serbia are the preparation of the tentative list, the preparation of an example of the nomination file (Viminacium is the site that has been chosen), to improve the presentation of the sites where it is possible and to prepare a web site and a booklet for our section of the limes.

\section{ROMAN LIMES IN SERBIA AN OVERVIEW}

Limes in Serbia is a natural extension of this project, especially recommended by the UNESCO authorities. An advantage for inscribing the limes in Serbia to the World Heritage List is that all the major argumentation has already been justified and attested. This would be the main obstacle for nomination. The basic undertakings of Serbian archaeologists now are to finish the recording of all the sites, prepare technical documentation and make a detailed assessment of the situation in the field. The selection of the sites that will be inscribed to the list is of no less importance, since not all of them can be included. The relationship with the local population to the site is one of the most important issues.

Unfortunately, no previous steps towards the nomination of the limes have been taken. The advantage of our long term archaeological research is that many sites are excavated, identified and, at least partially, published. This is an excellent springboard, since at least the tentative list can be prepared without major research.

European countries that are along the river Danube have different lengths of frontiers, but generally, as it was proven during meetings and study visits, all are faced with similar problems.

Comparative lengths of the river Danube in the countries included in the process of nomination:

$$
\begin{aligned}
& \text { Austria }-357 \mathrm{~km} \\
& \text { Slovakia }-72 \mathrm{~km} \\
& \text { Hungary }-417 \mathrm{~km} \\
& \text { Croatia }-137 \mathrm{~km} \\
& \text { Serbia }-587 \mathrm{~km} \\
& \text { Bulgaria }-471 \mathrm{~km} \\
& \text { Romania }-1075 \mathrm{~km}
\end{aligned}
$$

As seen from the overview, Serbia has a significant part of Danube length (587 km). Where the Roman frontier is concerned, the length of the Serbian limes section is actually $450 \mathrm{~km}$. Serbia 


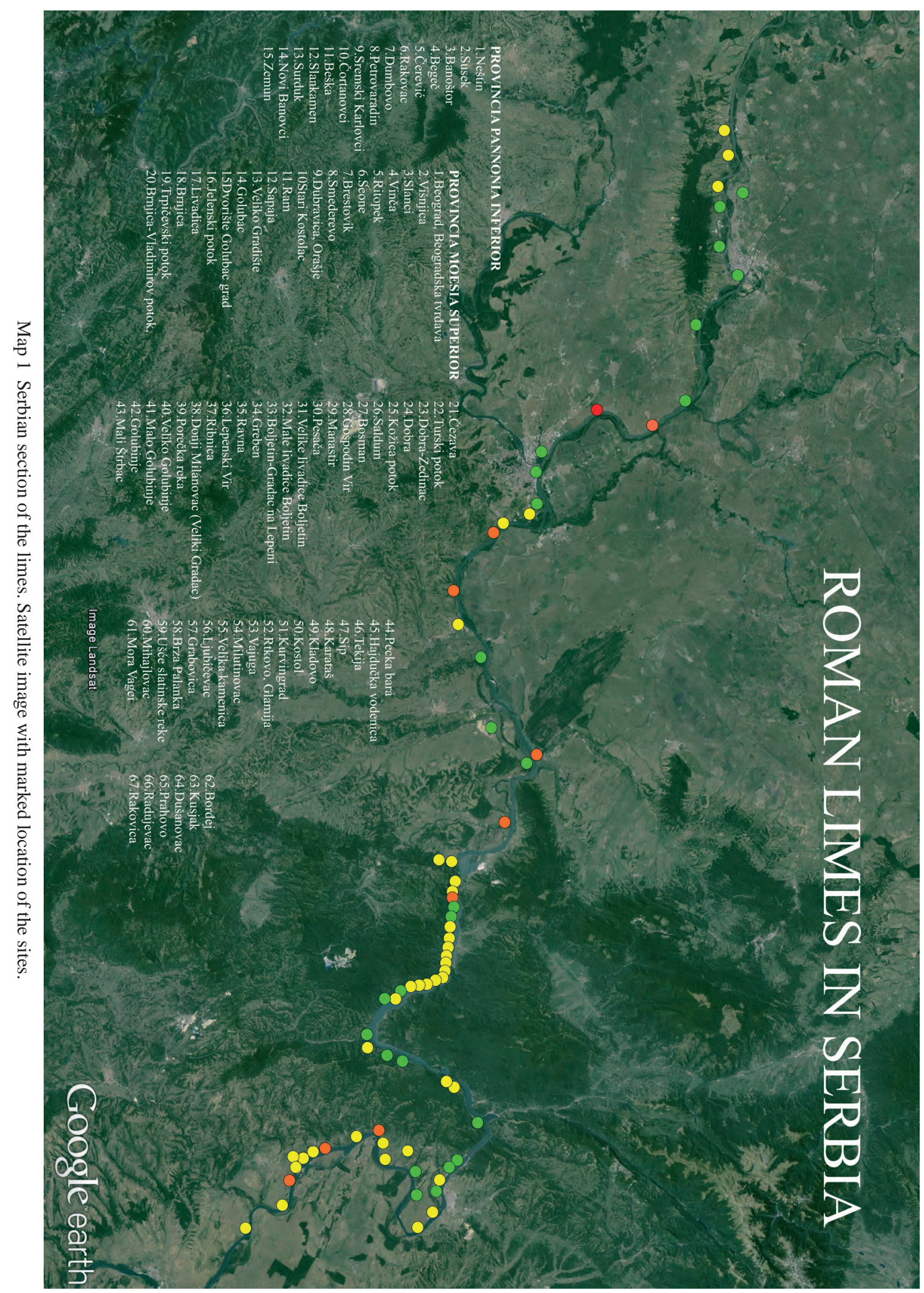




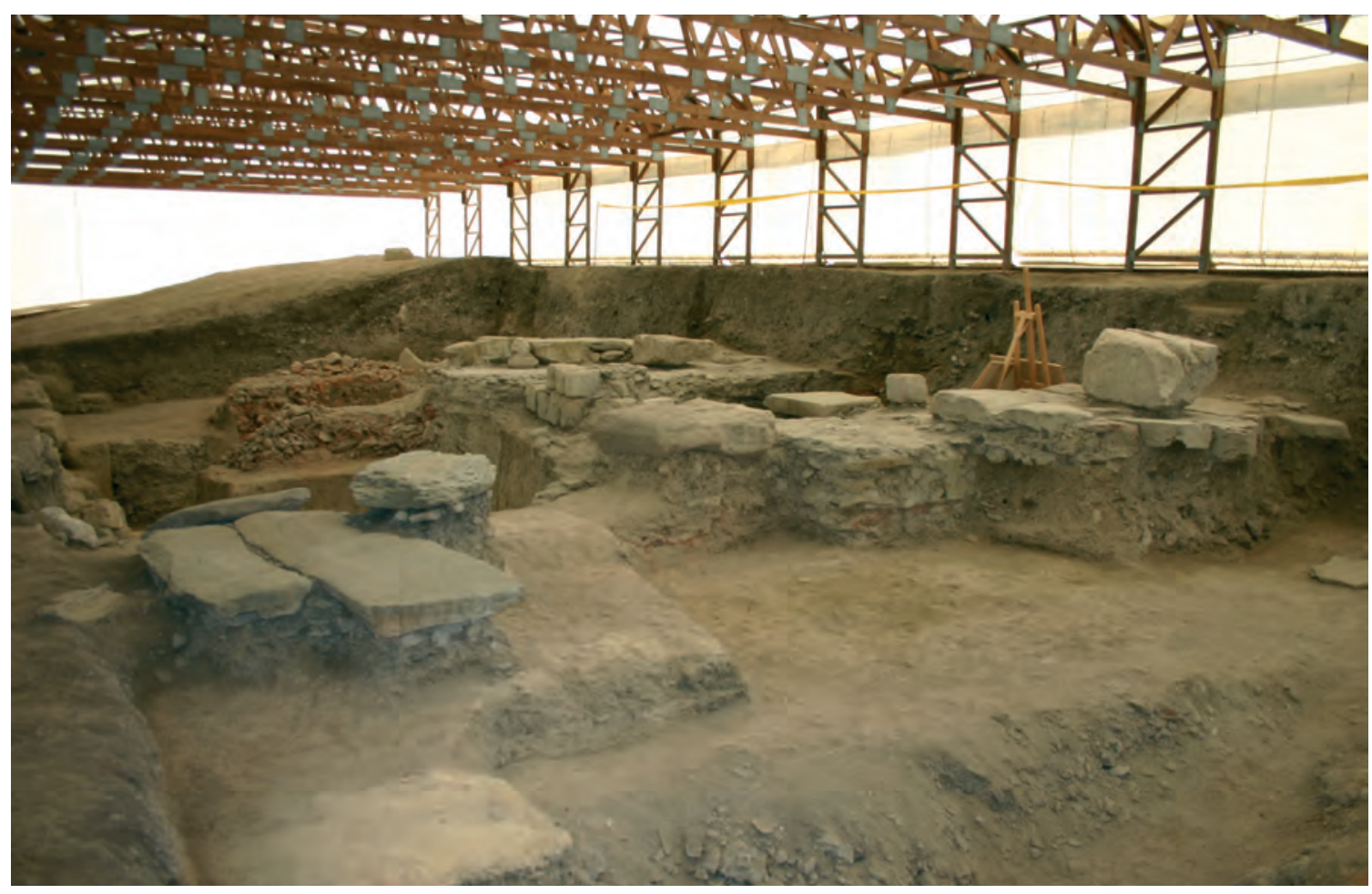

Fig. 5 Viminacium - Porta praetoria of the legionary fort

and Croatia share $137 \mathrm{~km}$, where Serbia holds the left bank that is, in fact, part of Barbaricum. Along the rest of the length that Serbia holds, either both or only the right river bank was part of the Empire. This means that almost 100-120 sites of different character can be expected in this zone. At least 80 sites are so far documented and partially published (map 1). Unfortunately, half of this number has not completed the procedure of legal protection. Only a few sites have physical protection, video surveillance or a guard service.

Archaeological research on the sites of the Serbian Limes Section has lasted for more than 130 years. However, unfortunately, not all parts of the limes are equally explored and published.

Geographically, the limes in Serbia can be divided into 4 sections:

Section 1: Lower Pannonian section from Neštin (border with Croatia) to Taurunum.

Section 2: Upper Moesian part from Singidunum to Cuppae.

Section 3: Iron Gate gorge (Djerdap I)

Section 4: Part of the limes from Pontes to Radujevac/Rakovica (Djerdap II)

This division more or less corresponds to the regional institutional jurisdictions discussed in the next chapter.
The Lower Pannonian section (section 1) was explored during the mid $\mathrm{XX}^{\text {th }}$ century, but almost no excavations were undertaken in the past several decades. Section 2 was explored only at the strong points and major cities like Singidunum, Margum and Viminacium. The space between is either not known or not adequately explored. The best known limes section is the area of the Iron Gates and downstream towards the Bulgarian border (Sections 3 and 4). During protective excavations in the 1960's and 1970's (Projects Djerdap I and Djerdap II) systematic excavations of numerous sites were undertaken. Unfortunately, many sites in this section were submerged under water when the level of The Danube rose after the building of the dams for the hydroelectric power plants Djerdap I and Djerdap II.

The first inspection of existing documentation confirmed that our section of the limes will meet all the criteria published in the UNESCO Guidelines 2005. Furthermore, there are at least three sites along the Limes that could meet the first criteria - to represent a masterpiece of human creative genius. These sites are:

The Roman road through the Iron Gates with imperial tablet (better known as Trajan's tablet). Parts of roman road are now almost com- 


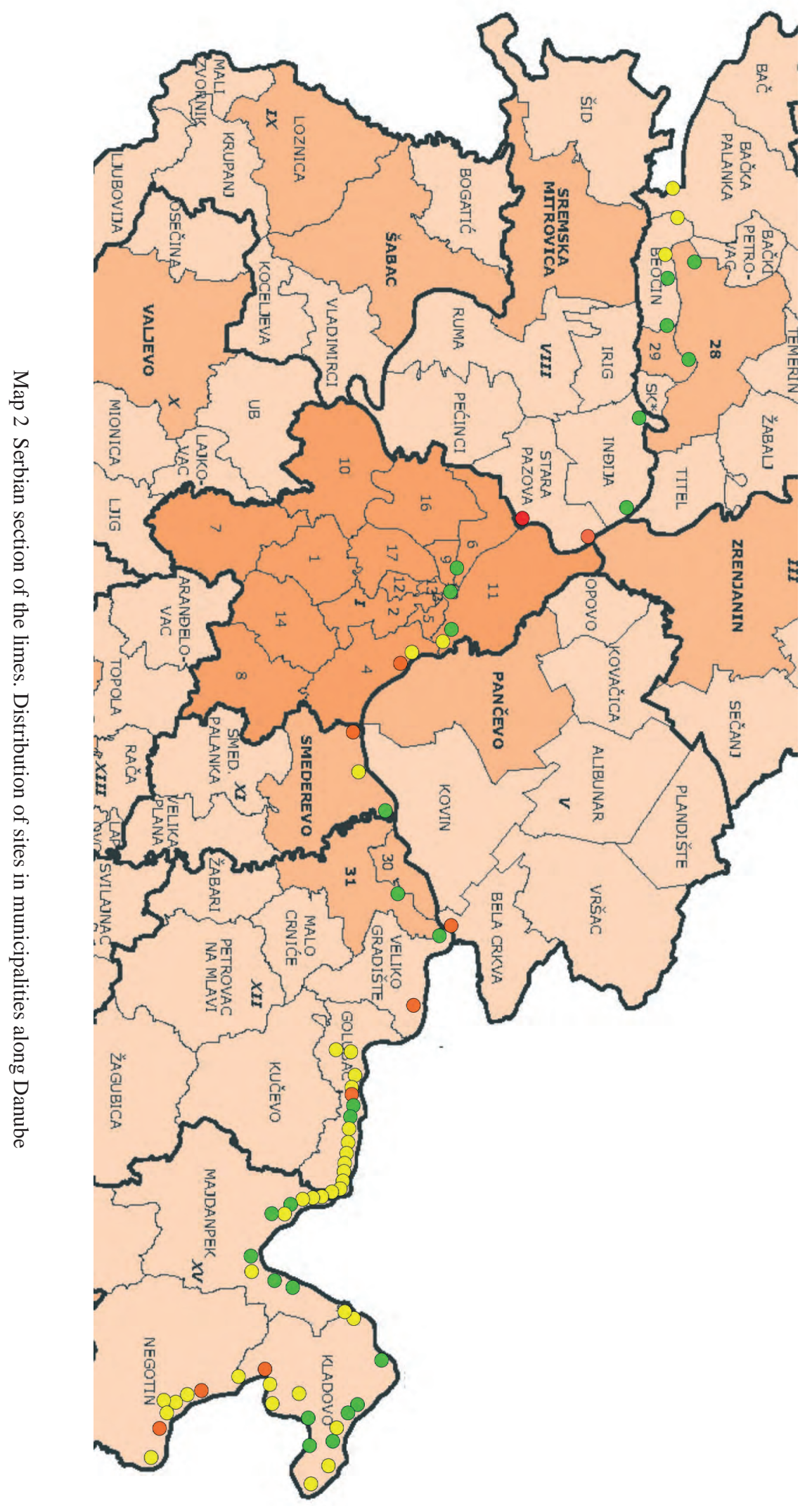




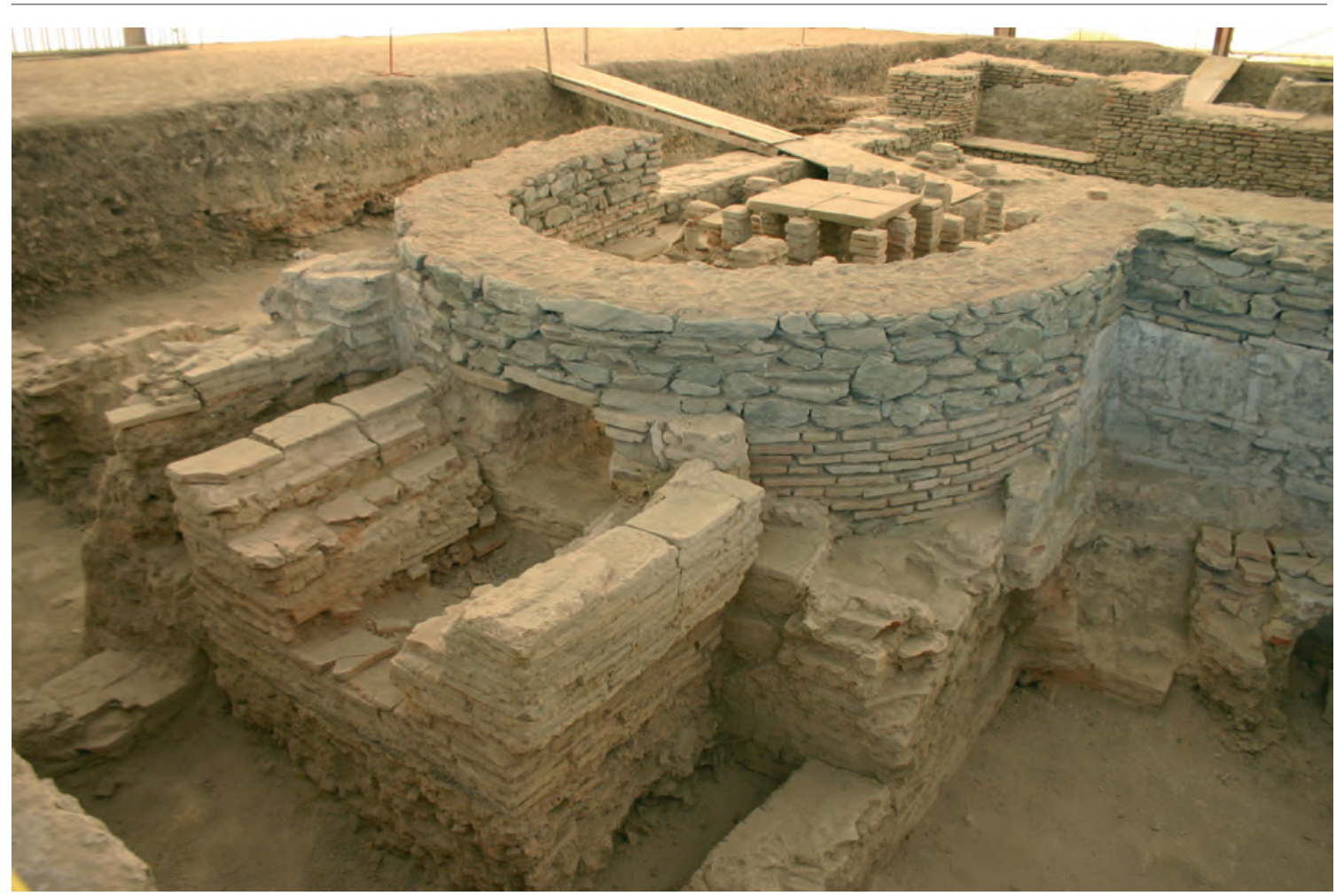

Fig. 6 Viminacium - City Thermae

pletely submerged under the waters of The Danube. Only the section under Trajan's tablet was relocated to a higher location and is still visible.

Trajan's canal at Sip with the Diana fort. Unfortunately, the canal is now completely destroyed and there are no elements for nomination. On the other hand, Diana is among the best preserved, excavated and presented sites on our section of limes.

Trajan's bridge over The Danube between Pontes (right bank - Kostol, Serbia) and Drobeta (left bank - Drobeta - Turnu Severin, Romania), with the fortification of Pontes (Transdrobeta). Remains along the bank are visible, conserved and presented. The fort protecting access to the bridge was also excavated, conserved and partially presented. Pillars that were in the middle of the river are also partially preserved.

It is now clear that many of the sites are endangered or have been almost completely destroyed since preliminary research was done in previous decades. The best examples of many problems faced along The Danube are Burgenae (Novi Banovci) and Lederata (Ram). Burgenae is completely over built by a weekend settlement and it will be almost impossible to nominate this fort for the UNESCO World Heritage List. Roman Lederata, on the hill above modern Ram, is out of sight of the local population and is systematically looted. The trenches of looters who destroyed the Roman remains are visible, even from the satellite.

The situation at the sites differs enormously. Some sites, like Singidunum are under modern settlements. Elements of a Roman legionary fort (Fig. 1-2) are under Kalemegdan Park and the Belgrade fort. A Roman city is under the modern city centre. The possibility for the presentation of antique architecture is fairly limited, but almost all the infrastructure still exists. On the other hand, Viminacium city and the legionary fort (Fig. 3-6) are away from modern settlements. Nothing is visible above the surface, but the buildings are well preserved. There are unlimited possibilities for the presentation, reconstruction and visualisation, but all the infrastructure will have to be built from zero. In the eastern section, sites are either under modern settlements or very close to them. Sites like Diana (Fig. 7-10) and Pontes (Fig. 1114) are well preserved and have excellent possibilities for presentation. Partial infrastructure exists, but a lot of investment is needed to put everything 


\begin{tabular}{|c|c|c|c|}
\hline \multicolumn{4}{|c|}{ Pannonia Inferior (Lower Pannonia) } \\
\hline $\begin{array}{l}\text { NOVI } \\
\text { SAD } \\
\text { Municipalities } \\
\text { Bačka Palanka } \\
\text { Beočin } \\
\text { Novi Sad } \\
\text { Petrovaradin }\end{array}$ & $\begin{array}{l}\text { SREMSKA } \\
\text { MITROVICA } \\
\text { Municipalities } \\
\text { Šid } \\
\text { Sremska Mitrovica } \\
\text { Irig } \\
\text { Inđija } \\
\text { Stara Pazova }\end{array}$ & & \\
\hline \multicolumn{4}{|c|}{ Moesia Superior (Upper Moesia) } \\
\hline $\begin{array}{l}\text { BELGRADE } \\
\text { Municipalities } \\
\text { Zemun } \\
\text { Novi Beograd } \\
\text { Stari grad } \\
\text { Palilula } \\
\text { Grocka }\end{array}$ & $\begin{array}{l}\text { SMEDEREVO } \\
\text { Municipalities } \\
\text { Smederevo }\end{array}$ & $\begin{array}{l}\text { POŽAREVAC } \\
\text { Municipalities } \\
\text { Kostolac } \\
\text { Požarevac } \\
\text { Veliko Gradište } \\
\text { Golubac }\end{array}$ & $\begin{array}{l}\text { BOR } \\
\text { Municipalities } \\
\text { Majdanpek } \\
\text { Kladovo } \\
\text { Negotin }\end{array}$ \\
\hline
\end{tabular}

Table 2 - Overview of the local authorities in the area of the Roman frontier on The Danube

into service for tourism. There is one especially interesting idea to use hologram technology for the visualisation of the Roman Bridge without interfering with the navigation of modern ships.

\section{INSTITUTIONS INVOLVED IN THE PROCESS OF THE NOMINATION}

Inscribing the site to the UNESCO World Heritage List is a project of the highest national importance. A problem that usually appears during the process of nomination is the number of institutions involved in the preparation of documentation, and their mutual coordination.

National level institutions:

- Archaeological Institute of Belgrade

- Institute for the Protection of Cultural Heritage of the Republic of Serbia

- National Museum of Belgrade

Regional institutes for the protection of cultural monuments:

- Provincial Institute for the Protection of Cultural Monuments, Novi Sad

- Institute for the Protection of Cultural Monu- ments of the city Novi Sad

- Regional Institute for the Preservation of Cultural Monuments, Sremska Mitrovica

- The Cultural Heritage Protection Institute of the City of Belgrade

- Regional Institute for the Preservation of Cultural Monuments, Smederevo

- Regional Institute for the Preservation of Cultural Monuments, Niš

Regional Museums:

- Museum of Vojvodina, Novi Sad

- Museum of Srem, Sremska Mitrovica

- City Museum of Belgrade

- Regional Museum of Smederevo

- Regional Museum of Požarevac

- Archaeological Museum of the Iron Gates, Kladovo

- Regional Museum of Negotin

Among the stakeholders in the Danube area, it is necessary to include The Electric Power Industry of Serbia in all major activities. It has facilities in the vicinity of some of the crucial archaeological sites. The Accumulative Lake Djerdap directly influenced the Serbian limes section because the rising water level resulted in dozens 


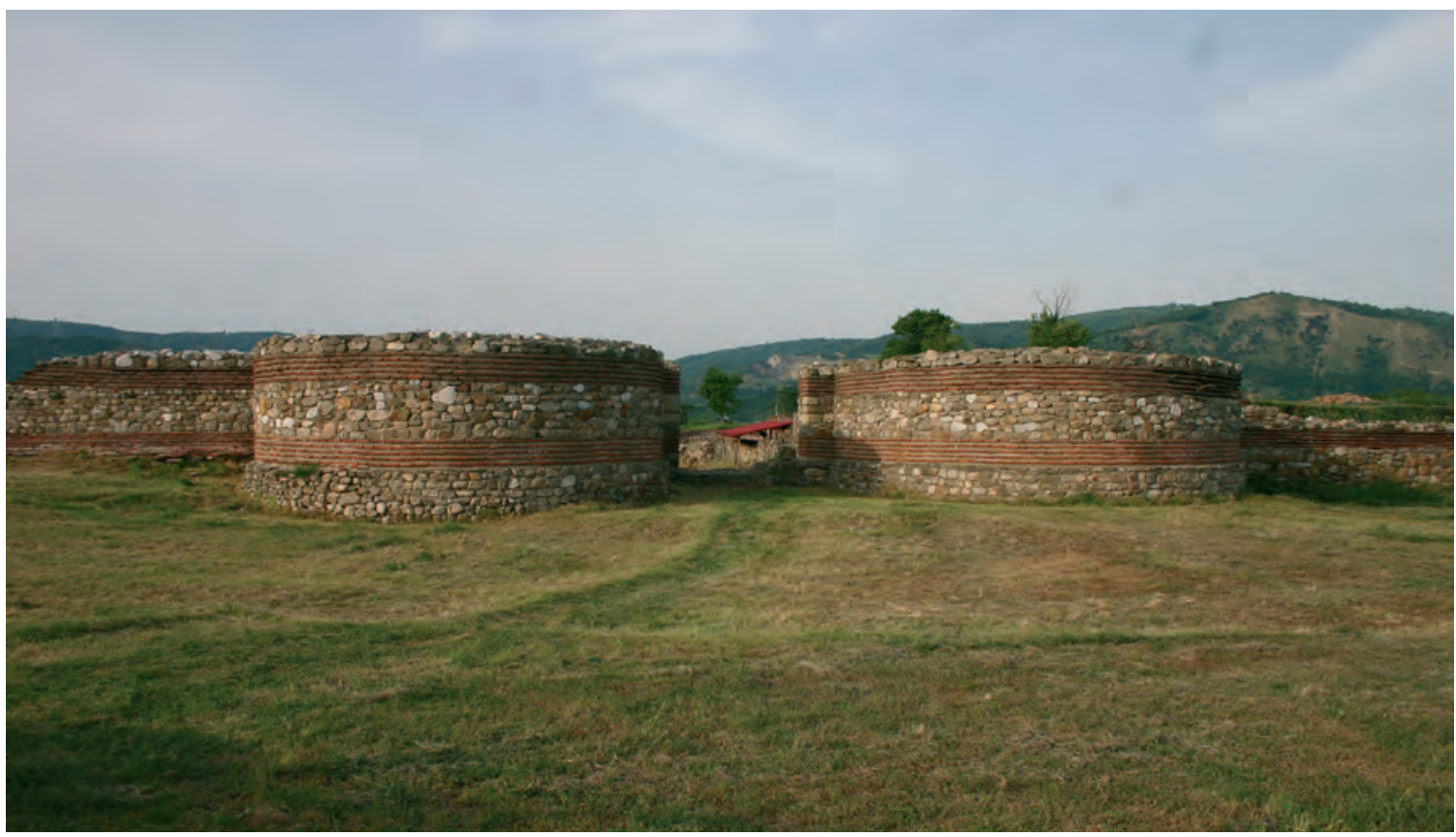

Fig. 7 Diana (Statio Cataractarum Dianae) - South Gate

of sites being submerged.

The Electric Power Industry of Serbia can, and often does, influence local and regional development and financing and can help with site management. Here, we should specially distinguish the thermoelectric power plants "Kostolac A" and "Kostolac B", the open pit coal mine "Drmno" and the hydroelectric power plants "Djerdap I" and "Djerdap II".

Cooperation with the municipalities along The Danube is also of crucial importance to the nomination. The maintenance, protection, management and utilisation of all sites depends a lot on local authorities. Therefore, it is also imperative to have good communication with the local population and to achieve their awareness of the importance that these sites have on the level of the entire humanity. The number of municipalities is large (Table 2) and they must all take part in the nomination of properties.

\section{GOALS OF THE NATIONAL NOMINATION PREPARATION}

- Preparation of the Serbian Limes Section UNESCO Tentative list

- Preparation of the nomination files for the sites of the Serbian Limes Section
- Scientific and documentation database for the sites

- Detailed archaeological map of the Serbian Limes Section

- Publication of all the material that is related to the Serbian Limes Section

\section{ARCHAEOLOGICAL DATABASE AND DETAILED ARCHAEOLOGI- CAL MAP OF SITES}

Research that started more than hundred years ago produced an enormous quantity of results and information. A lot of these results have been published, but far more was never processed or analysed. The documentation was scattered among many institutions and was never completed. Many sites that have been excavated and even partially published were never processed among top institutions and, therefore, do not have the appropriate level of legal and, especially, physical protection.

One of the bases for a future nomination would be the formation of a comprehensive database of all roman archaeological sites along the limes.

A preliminary database is filled with data that is already published and available to the re- 


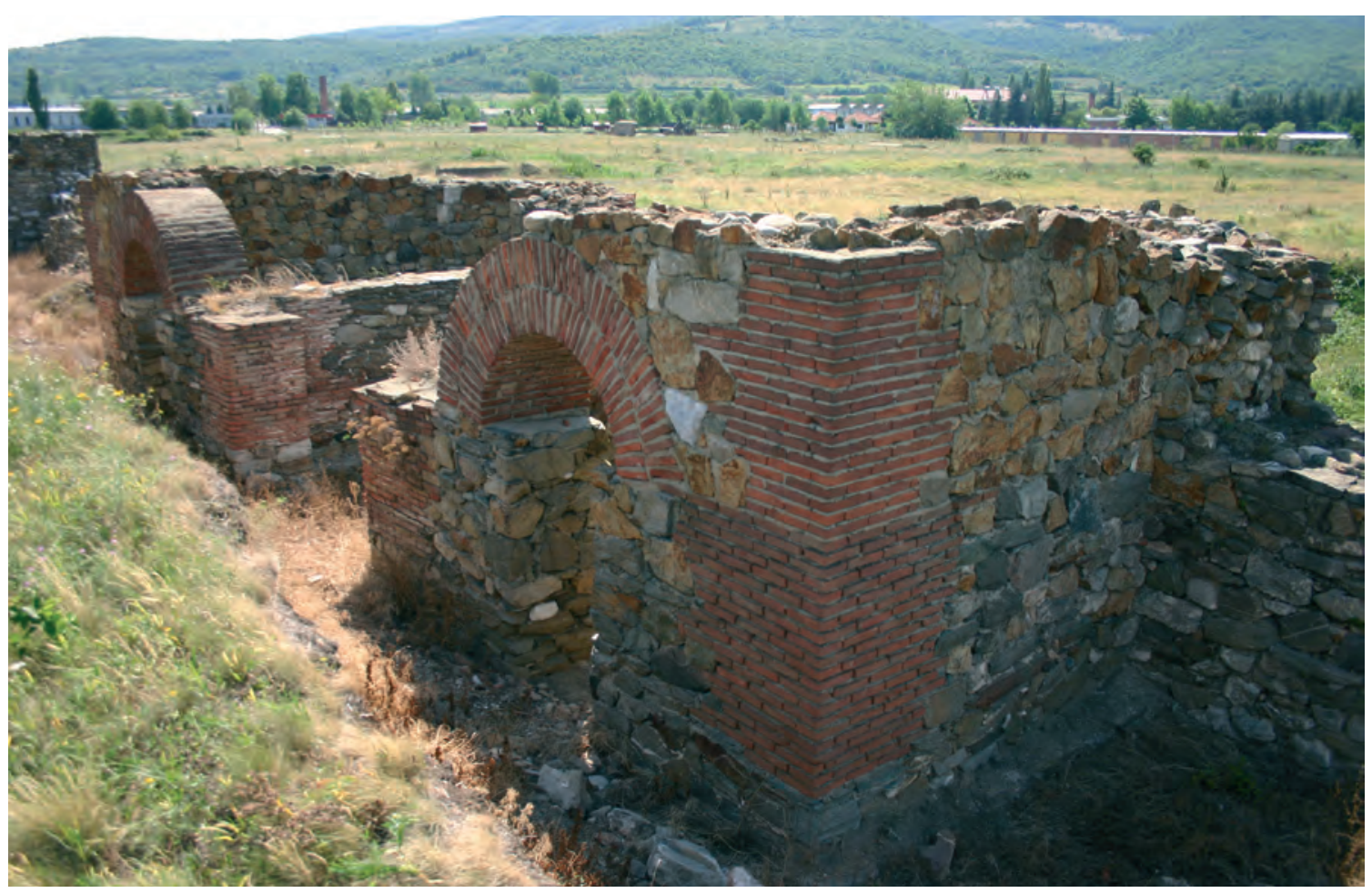

Fig. 8 Diana (Statio Cataractarum Dianae) - West Gate

searchers. The next step would be the implementation of data that is not published from the local documentations of national and regional institutions.

Naturally, it is also very important to survey all the sites, acquire precise coordinates and document the state of the heritage. The problem is that many sites have not been visited by experts in decades. The coordinates of many sites do not exist, due to different documenting methods. One of the problems is the lack of precise coordinates for sites that are submerged in the Iron Gates. During salvage excavations in the 1960's, coordinates were not regularly acquired and now these sites are not visible any more. One of the solutions to this problem is to acquire these coordinates from the old geo-referenced aerial images from the time of the excavations (1960-1970).

This database will be also a fundamental tool for the planning of conservation and presentation activities. It is also going to help with the utilisation of regional and local tourist and economic potentials.

\section{CONCLUSION}

The benefits of becoming a world heritage site are enormous. The development of tourism and the regional economy that normally follows this achievement greatly improves the quality of life of the local populations and brings international prestige. The obligations of the national and local government are now greatly enlarged. Financial expenses, as well as income, rise due to larger tourist traffic. However, all the efforts are futile unless the local population accepts the duty of the protection and management of the property. People living in the vicinity are the first line of defence, and without their cooperation central government has little chance to succeed in managing the site. Being a world heritage site also has limitations that sometimes discourage people from supporting the nomination. These limitations are primarily focused on the prevention of building activities and continuous maintenance.

Since there is a $450 \mathrm{~km}$ line to be presented and managed, it is suggested to organise regional centres for better control of the UNESCO properties. So far, the idea is to organize 4 centres as regional hubs. The centre for the Srem area 


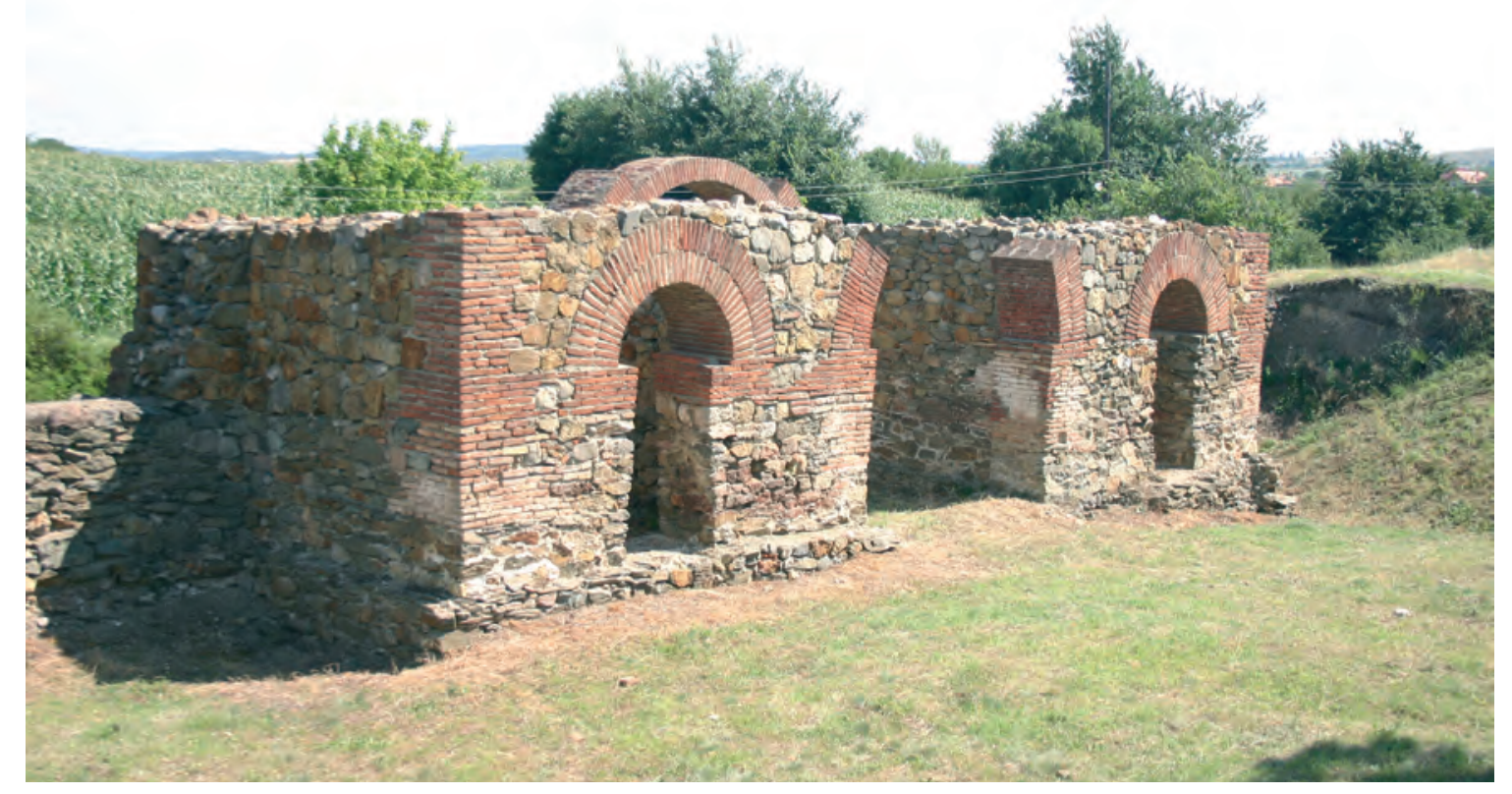

Fig. 9 Diana (Statio Cataractarum Dianae) - East Gate

could be Novi Sad. Belgrade and Viminacium could manage the central zone. Kladovo would be the eastern centre, controlling Iron Gates and the area downstream to Bulgaria. There is also a suggestion to appoint one central institution that would be the coordinator for the entire area of the Limes. This tends to be a problem because none of the existing centres has sufficient financial or human resources for this task. In ideal conditions, Government would found a new and specialised institution. However, this is unlikely in present financial and political environment.

Being part of the World Heritage List is the ultimate recognition of international value. The responsibility of maintaining this status is probably an even harder task than the nomination itself. Whatever the outcome of all of our efforts, the preservation of the Roman heritage for future generations remains the true legacy of this project.

\section{BIBLIOGRAPHY}

\section{Breeze, D. 2009}

The Antonine Wall, A World Heritage Site. Edinburgh, Historic Scotland.

Danube Limes Brand; official project web site Danube Limes Brand; http://danubelimesbrand. org/

\section{Danube Limes site}

Danube Limes; http://www.danube-limes.eu

\section{Jilek, S. 2009}

The Danube Limes A Roman River Frontier. Warsaw, Hussar Books.

\section{Jilek et al 2011}

Jilek, S. Kuttner, E. Schwartz, A. The Danube Limes in Austria. Vienna. Hussar Books.

\section{Lesak et al 2013}

Lesak, B. Musilova M. Resutik, B. Harmadyova, K. Rajtar, J. Schmidtova, J. Slovakia. Municipal Monument Preservation Institute. 


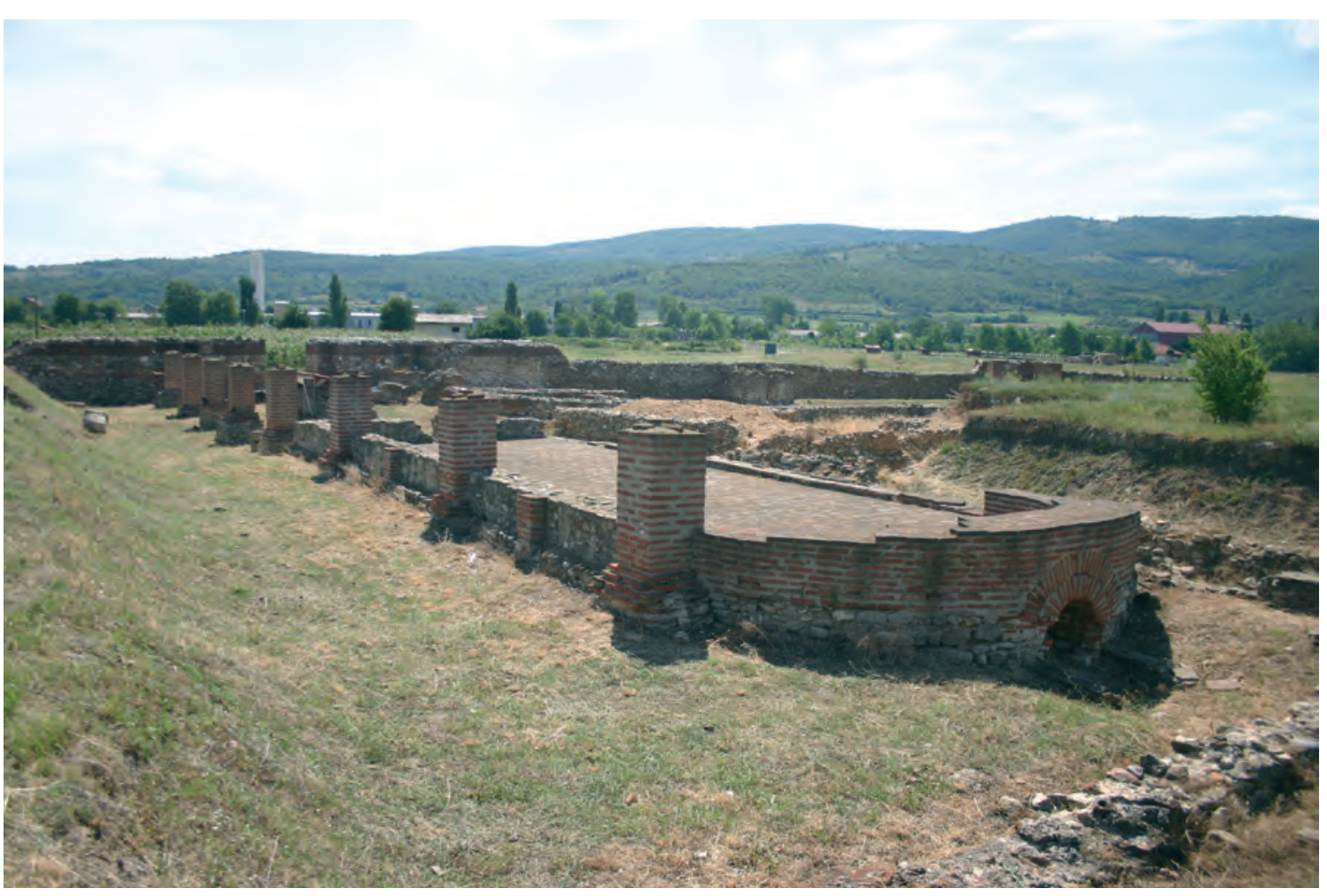

Fig. 10 Diana (Statio Cataractarum Dianae) - Presented buildings in the fort

Matingly et al 2013

Matingly, D. Rushworth, A. Sterry, M. Leitch, V. The African Frontiers. Edinburgh, Hussar Books.

\section{UNESCO, Official web site}

UNESCO; http://whc.unesco.org

\section{REZIME}

\section{DUNAVSKI LIMES KAO JEDAN OD LOKALITETA NA UNESCO-VOJ LISTI SVETSKE KULTURNE BAŠTINE}

Rimska vojna granica ili limes je neprekidna linija utvrđenja spojenih sistemom rečnih i kopnenih puteva sa osnovnim ciljem da se odbrani unutrašnjost Carstva od upada varvarskih plemena. Velike reke kao što su Dunav i Rajna iskorišćene su kao primarne barijere protiv ovih napada. Granica se prostire preko tri kontinenta i sastoji se od niza od više hiljada lokaliteta koji pripadaju različitim kategorijama počev od naselja, legijskih logora, manjih i većih utvrđenja za pomoćne jedinice, kula os- matračnica i brojnih naselja i nekropola koja su se formirala u njihovoj blizini.

„Granice rimske imperije“ su kompleksno i međunarodno kulturno dobro pod zaštitom UNESCO-a. To je jedan od najvećih projekata zaštite u okvirima svetske arheologije. Limes ispunjava tri od šest kriterijuma za nominaciju kulturnih dobara na listu svetske baštine. To su kriterijumi 2, 3 i 4. Delovi limesa koji se nalaze u Velikoj Britaniji i Nemačkoj već su upisani na listu svetske kulturne baštine 1987, 2005. i 2008. godine. Austrija, Slovačka, Mađarska i Hrvatska uveliko su započele nominacijske procedure. Njihovi delovi limesa već se nalaze i na UNESCO-vim preliminarnim listama (UNESCO Tentative list).

Limes u Srbiji je prirodan nastavak ovog projekta koji je i preporučen od strane UNESCO-a. Prednost za upis srpskog dela limesa na listu svetske kulturne baštine je upravo ta da je glavna argumentacija već napisana, priložena i prihvaćena. Osnovni zadatak arheologa u Srbiji je da se završi dokumentovanje lokaliteta, pripremi tehnička dokumentacija i izradi detaljna procena situacije na terenu. Izbor lokaliteta koji će biti upisani na listu kulturne baštine nije od manje važnosti, kao 


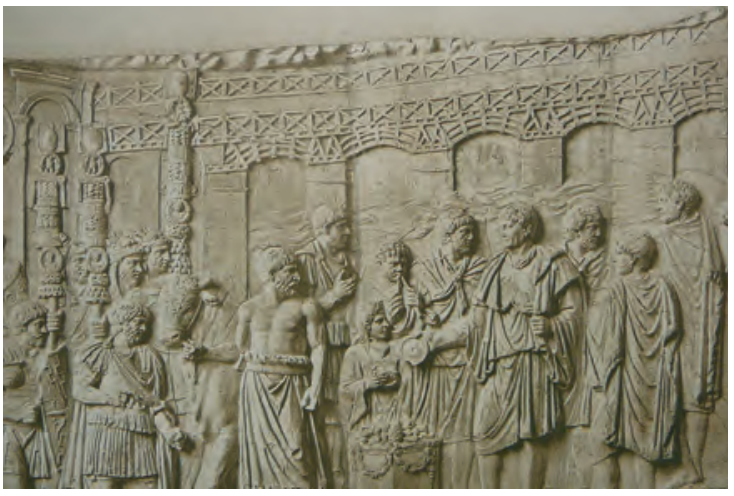

Fig. 11 Pontes / Trajan Bridge - Relief on Trajan’s Column in Rome

ni odnos lokalnog stanovništva prema onome što poseduju u svojoj neposrednoj blizini.

Upis na listu podrazumeva da su lokaliteti fizički zaštićeni, prezentovani i da imaju organizovano upravljanje. Upravo kada je u pitanju upravljanje, važan je odnos lokalne vlasti i stanovništva prema sopstvenom kulturnom nasleđu. Bez obzira na državne institucije ljudi koji žive u neposrednoj blizini lokaliteta čine njegovu prvu liniju zaštite. Pošto situacija nije u potpunosti onakva kakva je propisana normama UNESCO-a, potrebno je uložiti puno energije u njeno stvaranje. Efikasan sistem up-

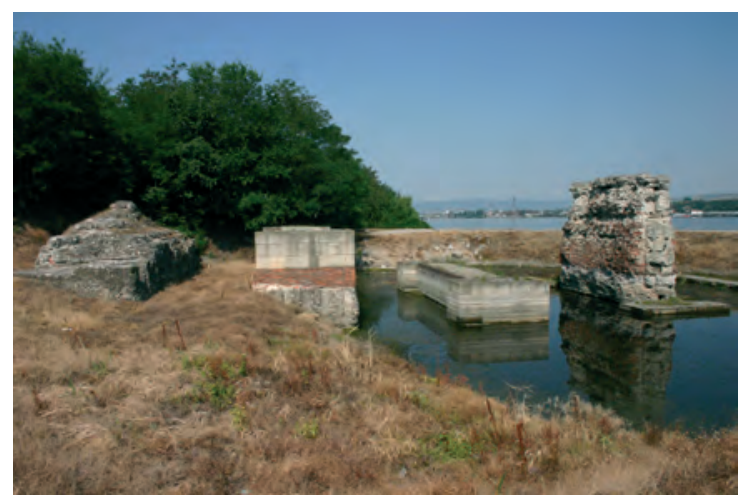

Fig. 12 Pontes / Trajan Bridge - Architectural remains on the right bank of the Danube

ravljanja u potpunosti zavisi od pojedinačnih slučajeva, vrste lokaliteta, njegovih karakteristika, potrebe i opšteg kulturnog konteksta. Državne institucije, regionalna i lokalna uprava moraju biti uključeni u pripremu za nominaciju i prezentaciju arheoloških ostataka. Popularizacija i edukacija u vezi sa ovim segmentima rimskog nasleđa su neizostavni delovi rada sa stanovništvom kako bi se podigla svest o njegovoj važnosti, o prednostima zaštite ovakvih objekata i ključa njegovog očuvanja. Dosta lokaliteta je ili u velikoj meri kroz istoriju potpuno devastirano ili za stanovništvo predstavljaju samo izvor besplatnog

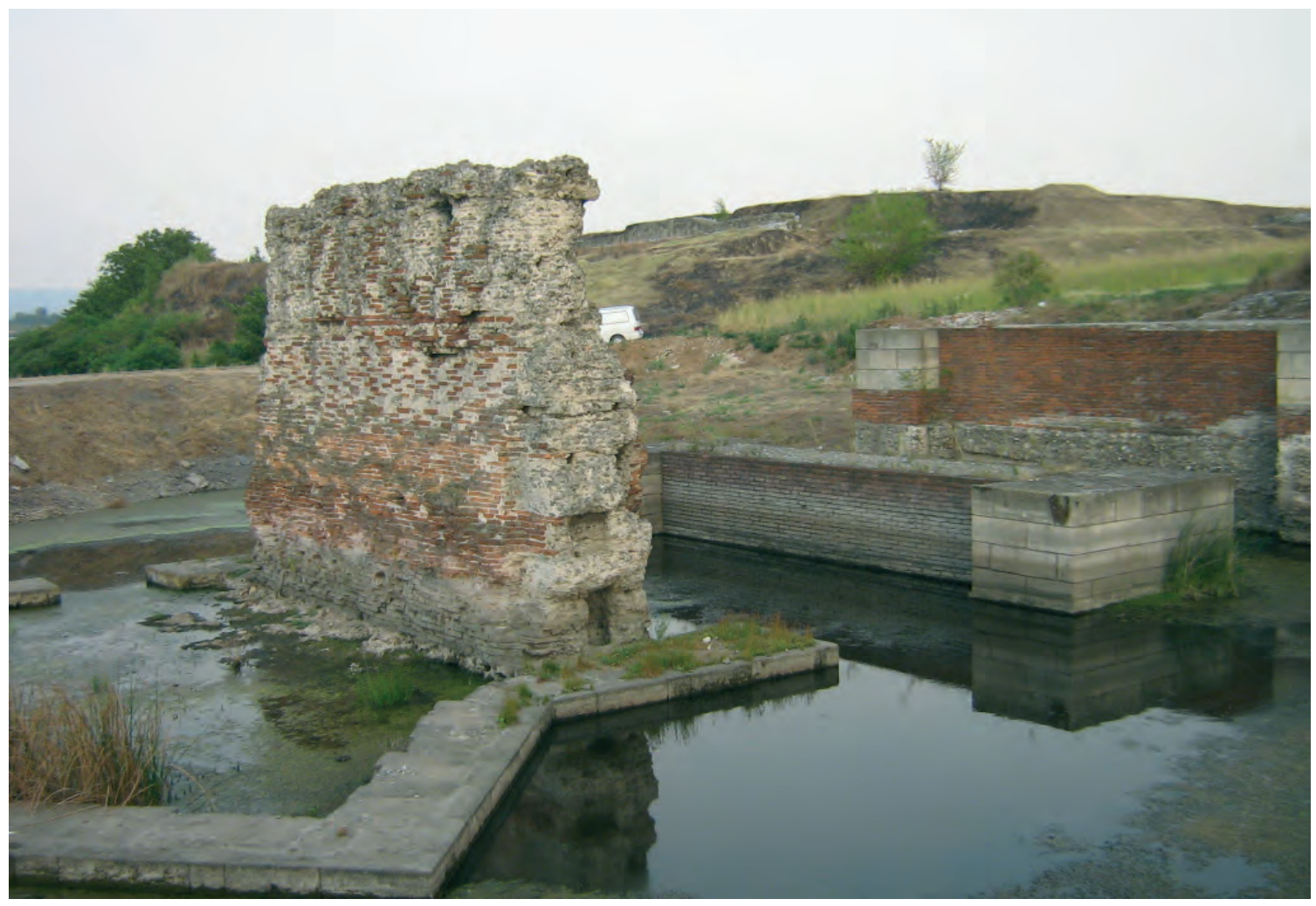

Fig. 13 Pontes / Trajan Bridge - Remains of the bridge and fort in the background 


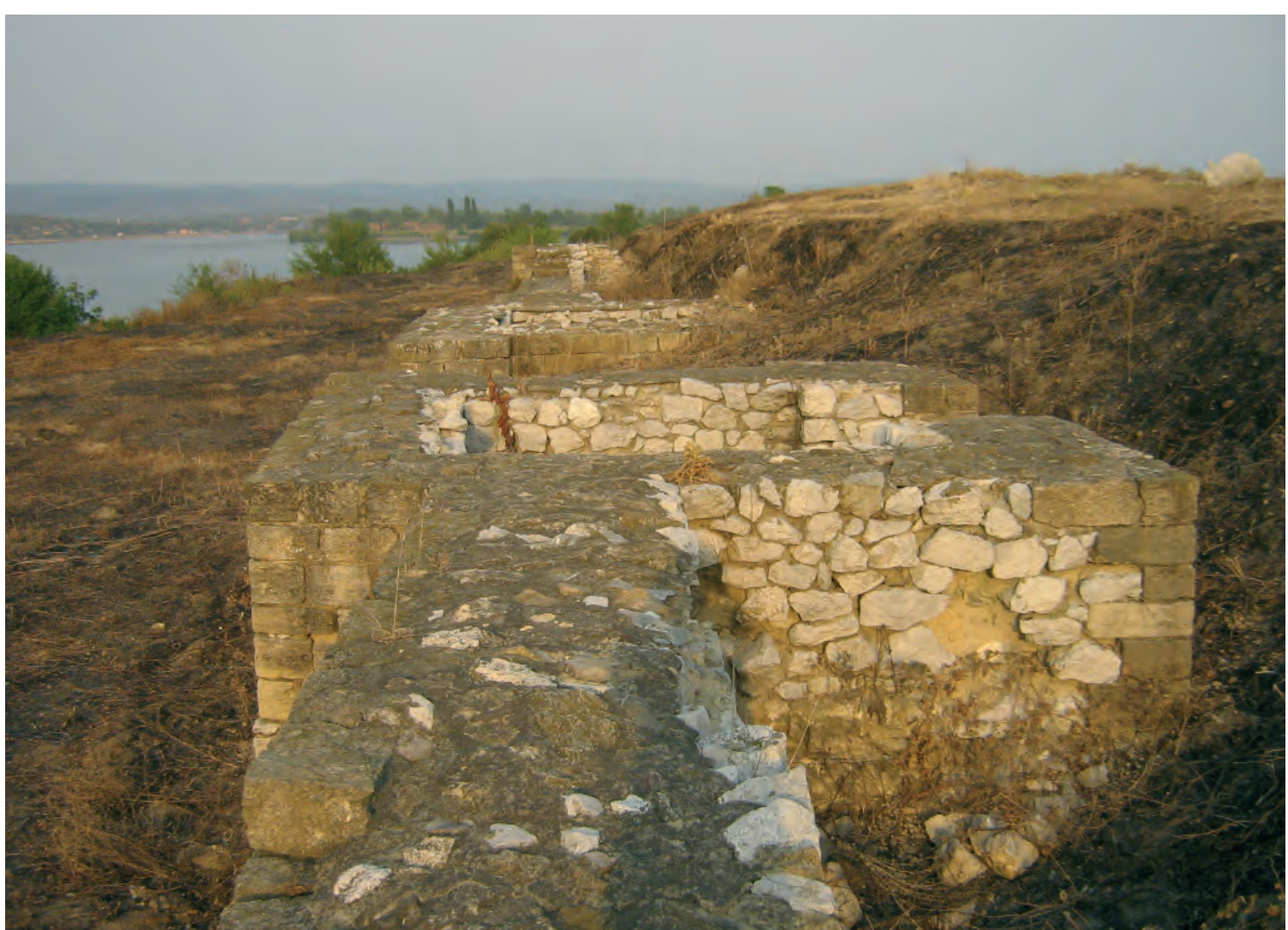

Fig. 14 Pontes - Fort, West gate

građevinskog materijala. Toj populaciji potrebno je posvetiti posebnu pažnju i odgovarajućim pristupom ih dovesti do saznanja zašto je upravo ta "ruševina" deo kulturne baštine sveta.

Kada su najveći lokaliteti u pitanju, prezentacija i zaštita dunavskog limesa u Srbiji je deo već postojećeg projekta Itinerarium Romanum Serbiae (Putevima rimskih imperatora) koji je priznat od stručnjaka Srbije i Evropske Unije. 